\title{
Modeling the Incidence of Yellowing Diseases to Whiteflies and Alternative Host
}

\author{
Ida Bagus Bagus Gde Pranatayana ${ }^{1}$, I Putu Sudiarta ${ }^{2}$, Ali Nurmasyah ${ }^{3}$ \\ 1* Tourism Management, Bali International Business and Tourism Institute, Indonesia \\ ${ }^{2}$ Biotechnology of Agriculture, Udayana University, Indonesia \\ ${ }^{3}$ Plant Protection, Bogor Agriculture University, Indonesia \\ * Corresponding author. Email: pranatayanaibg@gmail.com
}

\begin{abstract}
Yellowing disease is one type of plant disease which is found in some of the centers of cultivation of yard long beans in Bali. The spread of yellowing diseases caused the presence of vector insects, such as whiteflies and alternative host plants, such as weeds and other crops. This problem is then examined through statistical modeling in order to determine the pattern of the relationship between the incidence of yellowing disease with the populations of whiteflies and the alternative host plants. Collection of data on the yellowing disease incidences, the abundance of whiteflies, and the existence of alternative host plants was done through a direct observation in 100 farmer fields in several centers of cultivation of yard long beans in Bali. Determination of the best mathematical model was performed by linear regression analysis with the ordinary least squares method. The results indicated that the best models for the relationship between the incidence of yellowing disease (IYD) with the population of whiteflies (WF) as well as the alternative host plants of yellowing were as follows: $I Y D=1,2265 W^{0,9872} A H P^{1,0936}\left(R^{2}=98,43 \%\right.$; P-value $\left.=0,000\right)$. The incidence of yellowing disease was highly significantly positively correlated with the population of whiteflies and yellowing symptomatic alternative host plants. The existence of alternative host plants around the field was very decisive in triggering the emergence of yellow virus disease in the crop.
\end{abstract}

Keywords: alternative host, model yellow disease, whiteflies, yard long bean

\section{Introduction}

Yard long beans (Vigna unguiculata sub sp. sesquipedalis L.) is a horticultural crop as native to Southeast Asia [15]. Yard long beans consumed by many people in Indonesia are caused by one type of legume that contains protein. One of the regions in Indonesia that is very consistent with cultivated yard long bean crops is Bali [15]. Begomovirus that causes yellowing has been reported in many types of plants such as on chilli pepper, tomato and tobacco caused by viral infection Pepper Yellow Leaf Curl Virus(PepYLCV), Tomato Yellow Leaf Curl Virus (TYLCV), and Tobacco Leaf Curl Virus (TLCV) are considered as the major factor causing yield loss, respectively [5], [10]. Association MYMIV (Mungbean Yellow Mosaic India Virus) with yellow yard long bean mosaic disease in Java [21].

The yellowing disease is an important disease caused by viruses that decrease yield on yard long beans in Bali. To date, has been reported that there were two types of viruses caused yellowing disease incidence on yard long bean is Mungbean yellow mosaic virus (MYMV) and Mungbean 
yellow mosaic India virus (MYMIV) [20], [21], [30], [11]. Occurrence of yellowing disease on yard long beans is determined by the presence of insect vectors and existence of alternative host plants [17].

Whiteflies type of Bemisia tabaci as insect vector on yellowing disease which in addition to insect pests also potential virus vector [32]. Declare that the higher the population of insect vectors, also the higher the incidence of viral diseases. The high yellowing viruses are associated with high populations of whiteflies as especially in the long dry season [7]. The existence of alternative host plants such as weeds and other crops is another factor that can also induce the appearance of the viral disease, in addition to insect vectors [2]. When the main crop that is yard long beans no available in the field the insect vector could be survived and evolve on the weeds and other crop growing around the main crop field cause, [1] claim that plant disease epidemic is affected by hosts, pathogens, environment, human activities, and tim. Therefore, the finding of virus in yard long beans caused by association with alternative vectors and hosts caused the virus to survive and replicate itself in alternative host plants. So that, at the time of yard long bean crops planted in the field, the viruses that live in alternative host plants will switch to planting yard long beans when insects vector these crops attack. With a growing number of alternative host plants such as Leguminosae, Cucurbitaceae and Solanaceae that are around land, the chance of yellowing disease incidence in the yard long beans is greater [17], [31].

Then, I need to do more in depth studies related to the virus epidemic which is a study of the interactions between the host plant and the viruses, host and vector, viruses and vectors, and the influence of the environment in the interaction. Because, until now, studies that focus on the analysis of the shape or pattern of the relationship between the incidence of viral diseases with insect vector populations and the existence of alternative host plants have never been there. Therefore, this research needs to be done in order to determine the relationship patterns between the incidence of yellowing disease with a population of whitefly, B. tabaci, and the existence of alternative host plants such as weeds and other crops.

\section{Material and Methods}

In this study three types of data, namely (1) the incidence of yellowing disease, (2) the abundance of whiteflies, and (3) the existence of alternative hosts yellowing virus. The third type of data collection is done on the direct observation yard long beans land owned by farmers.

Measurement yellowing disease incidence conducted through 100 farmers land by purposive sampling in several centre's of cultivation of yard long beans in Bali. Each plant in each area was observed by one and counted the total number of existing crops (n) and recorded separately the number of infected plants yellowing disease (b). Furthermore, the incidence of yellowing disease (IYD) is calculated with the following formula [29] :

$$
I Y D=\frac{b}{n} \times 100 \%
$$

Sampling of each insect vector is done in a systematic way on diagonal line plots. The number of plants observed is $10 \%$ of the total population. The Abundance of species of whiteflies $B$. tabaci was calculated by summing the nymphs on a number of plant samples. Abundant whiteflies nymphs are calculated based on the whole plant divided by the number of plants observed.

Posit about 30 to 50 leaves of all kinds of other crops and weeds growing around fields observations taken intentionally (purposive) as samples to detect the existence of yellowing symptoms and attack whiteflies. The identification was based on identical yellowing symptoms with symptoms of a viral disease on yard long beans until discovery of types of insect vector individuals 
in leaf samples. If found at least one type of alternative hosts, it can be said there are alternative hosts (value 1). Conversely, if one does not found an alternative host plant, it can be said there are no alternative hosts (value 0 ).

Based on the framework and research hypothesis described above, the relationship between the incidence of yellowing disease (IYD) with an abundance of whiteflies B. tabaci (WF), and the existence of alternative hosts plant (AHP) the formulated a mathematical model as below:

$$
\mathrm{IYD}=f(\mathrm{WF}, \mathrm{AHP})
$$

to declare $\mathrm{f}$ of the function (curve) for the corresponding mathematical relationship between variables affected (dependent variable $[\mathrm{KPK}]$ ) with the variables that affect it (the predictor variables $[\mathrm{KB}$, and TI]). Shape function (f) which can be applied to the relationship model above there are several possibilities, among which is a linear function $(\mathrm{Y}=\mathrm{a}+\mathrm{bX}+\mathrm{e})$, polynomial $(\mathrm{Y}=\mathrm{a}+\mathrm{b} 1 \mathrm{X}+\mathrm{b} 2 \mathrm{X} 2$ $+\ldots$ bn $\mathrm{Xn}+\mathrm{e})$, exponential $(\mathrm{Y}=\mathrm{aebX}+\mathrm{e})$, logarithmic $(\mathrm{Y}=\mathrm{a}+\mathrm{b} \log \mathrm{X}+\mathrm{e})$, power $(\mathrm{Y}=\mathrm{a} \mathrm{Xb}+$ e), or form other functions. Notation $Y$ symbolizes variables affected, $X$ variables that affect it, and e declare variables that affect $\mathrm{Y}$ and are not incorporated into the model ([error]).

Determining the best model for the relationship between the incidence of disease and the factors that affect it and estimation parameters (coefficients) of the chosen model made through a linear regression analysis with ordinary least squares method. Criteria used to determine the best model is the suitability statistical models, the $\mathrm{R}^{2}$ (corrected), Mallows Cp, AIC (Akaike Information Criterion), PRESS and the value of $\mathrm{F}$ in the table of variance (ANOVA) model testing. Determination of the variables that significantly affect the variables affected done by using t-student of the regression coefficients on the best model selected. All of the above analysis was done with Minitab software program version 17.0.

\section{Results and Discussion}

\subsection{Species of Alternative Host Plants Yellowing Disease and Symptom Characteristics}

Results of identifying the types of weeds that show symptoms of yellowing in detail can be seen in Table 1. Alternative host yellowing of weeds species detected as many as 9 species from 6 families.

Table 1

Types of weeds that are alternative hosts yellowing disease in yard long beans

\begin{tabular}{cllcc}
\hline No & Species & Family & Type of Weed & Life Cycle \\
\hline 1 & Ageratum conyzoides & Asteraceae & Broadleaf & Annual \\
2 & Eclipta prostrata & Asteraceae & Narrowleaf & Annual/Perennial \\
3 & Synedrella nodiflora & Asteraceae & Broadleaf & Annual \\
4 & Commelina diffusa & Commelinaceae & Narrowleaf & Annual/Perennial \\
5 & Euphorbia hirta & Euphorbiaceae & Narrowleaf & Annual \\
6 & Phyllanthus niruri & Euphorbiaceae & Narrowleaf & Annual \\
7 & Ipomoea sp & Convolvulaceae & Broadleaf & Abnual \\
8 & Amaranthus spinosus & Amaranthaceae & Broadleaf & Annual/Perennial \\
9 & Leucas lavandulaefolia & Lamiaceae & Broadleaf & Annual/Perennial \\
\hline
\end{tabular}

[28] Reported that weed species A. conyzoides, Ipomoea sp and A. spinous positively infected yellowing virus species of MYMV in yard long beans land in Bali. Eclipta alba is a weed species 
were reported also infected by MYMIV [16], so most likely the weed species E. prostrata were found in the yard long bean land in Bali are infected by the same virus cause as morphologically very identical with E. alba and comes of the family Asteraceae. For other crops, the identification results showed there were 4 species from 2 families.

Table 2

Other crops types into alternative host yellowing disease in yard long beans

\begin{tabular}{clc}
\hline No & Crop (species) & Family \\
\hline 1 & Peppers (Capsicum frutescens) & Solanaceae \\
2 & Tomatoes (Solanum lycopersicum) & Solanaceae \\
3 & Pumpkin (Cucurbita moschata) & Cucurbitaceae \\
4 & Mentimun (Cucumis sativus) & Cucurbitaceae \\
\hline
\end{tabular}

There are many reports of yellowing virus infection that infects crops including, [19] who reported a yellowing virus infection in tomatoes and peppers. Symptoms of yellowing appearing on the kind of alternative host plants in other crops (Table 2) can most likely be a source of inoculum MYMV despite the absence of scientific reports related to MYMV infections in its crops.

Characteristics of the yellowing virus in yard long beans in Bali showed typical symptoms that vein clearing (bone fading leaves) accompanied by a bright yellow color on almost the entire surface of the leaf such Figure 1 and characteristics yellowing symptom on weeds Figure 2 and other crop Figure 3.

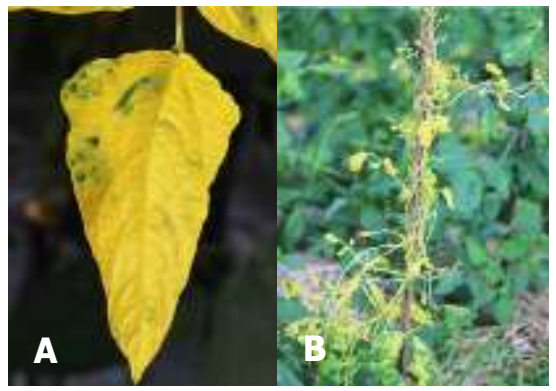

Figure 3

Symptoms of Yellowing on 4 species of other crop: (A) C. frutescens;

(B) S. lycopersicum; (C) C. moschata; (D) C. sativus.

\subsection{Determining the Best Model on Yellowing Disease}

Table 3

Four statistical criteria for the best model to model Yellowing disease

\begin{tabular}{lcccc}
\hline Model & $\mathrm{R}^{2}$ (correction) & Cp Mallows & AIC & PRESS \\
\hline Linier & 94,34 & 3 & 414,48 & 7835,96 \\
Logarithmic & 72,4 & 3 & 573,026 & 30955,7 \\
Polynomial & 96,73 & 4 & 414,48 & 5638,14 \\
Power & 98,39 & 3 & $-429,278$ & 1,87395 \\
Exponential & 62,84 & 3 & 51,641 & 169,063 \\
\hline
\end{tabular}

Results of statistical analysis for the fourth criterion of the best models from five candidates yellowing models in detail can be seen in Table 3. These results indicate that the best model is the model of power because it has value $\mathrm{R}^{2}$ correction supreme (98,39\%), Cp Mallow equal to the 
number of model parameters (3), AIC lowest $(-429,278)$, and PRESS lowest $(1,87395)$. Thus, these results prove that the model of the power is the best model to describe the relationship between the incidence of yellowing in yard long beans with the existence of a population of whiteflies and alternative host plants around the land. Jager et al, 2018 claim that on a more localized scale, most models of environmental impacts have been based on regression or similar empirical statistical approaches, where comprehensive data sets on disease measures, such as incidence, severity, or prevalence, are related to weather variables relating to the different scales appropriate to the disease measures.

Based on multiple linear analysis of the variables affected logarithmic (log [IYD]) and the variables that affect the logarithm (Log $[\mathrm{WF}]$ and $\log [\mathrm{AHP})$ obtained the following results:

$$
\text { IYD }=1,2265 \mathrm{WF}^{0,9872} \mathrm{AHP}^{1,0936} \quad\left(\mathrm{R}^{2}=98,43 \% ; \mathrm{P} \text {-value }=0,000\right)
$$

F-test on the above model shows that the model is real on the real level of $1 \%$ ( $\mathrm{P}$-value $=0,000$ ). This model has a value of $\mathrm{R}^{2}=98,43 \%$, which means that the two variables that affect (the abundance of whiteflies $[\mathrm{WF}]$ and alternative hosts symptomatic yellowing [AHP]) were able to describe the extent of the incidence of yellowing disease by $98,43 \%$. This indicates that other factors not analyzed in this study, such as climatic conditions (temperature, humidity, and rainfall), contribute very low to the increasing incidence of yellowing disease, which amounted to $1,57 \%$.

$\mathrm{T}$ test results against coefficient variables that affect WF and AHP indicates that variable abundance of whiteflies and alternative host plants positively correlated highly significantly ( $\mathrm{p}$-value $<0,01$ ) on the incidence of yellowing disease on yard long beans (Table 4). These results can be drawn from each of the two variable coefficients. WF coefficient value is 0,9872 (Table 4) which means that every $1 \%$ increasing the abundance of whiteflies will be able to increase the incidence of yellowing disease by $0,99 \%$, on the condition variable presence of alternative hosts constant (ceteris paribus). While coefficients AHP variable is 1,0936 (Table 4) which showing that every $1 \%$ increase in the presence of alternative hosts yellowing symptoms will lead to increased incidence of yellowing disease in the yard long beans by $2,2 \%$, if the conditions of variable abundance of whiteflies constant (ceteris paribus). Based on the model of yellowing obtained above shows that the conditions whiteflies vector abundance of 1 individual per plant and there are alternative sources of inoculum symptomatic host plants yellow with a value of 1 would raise the incidence of yellowing amounted to $1.2265 \%$. However, if there are no alternative hosts (AHP $=0)$, then yellowing disease will not happen despite the vector around crop fields.

WF and AHP variable values in the model are relatively similar to the occurrences of yellowing disease in the yard long bean. This means whiteflies and alternative host plants have a similar role to the existence of the virus in nature. Yellowing virus infection to the plant can only occur through an intermediary whiteflies vector insect [6]. However, the coefficient KB is relatively the same as the armpits indicates that in addition to alternative hosts, which is used as a reservoir by the virus to survive, replicate and form a virus strain, whitefly also potentially provide a source of transmission main and the beginning and helped the existence of viruses in planting land besides be vector. This is due in addition to the alternative host plant, the virus is also able to survive at certain concentrations in the body of whiteflies even without replication [22]. Therefore, in addition to the existence of alternative host plants, whiteflies should be wary because it could potentially help the existence of the virus [15] especially in the long bean crop land.

The yellowing virus is not transmitted through seeds or is it transmitted by direct contact between plants, the virus is transmitted by whitefly (Bemisia tabaci) persistently [9], which means that throughout its life the virus is contained in the body of the tick [26], [12]. The viruses they 
transmit are often more harmful than the damage caused by the whitefly pests themselves, which decrease yield on yard long beans by up to $53.87 \%$ [24].

Table 4

Estimates of model coefficients yellowing and t-test, its model based on model of power

\begin{tabular}{lcccc}
\hline \multicolumn{1}{c}{ Variable } & Coefficient & $\begin{array}{c}\text { Standard error } \\
\text { coefficient }\end{array}$ & T & P-value \\
\hline Constants & 0,0887 & 0,0822 & 1,0783 & 0,284 \\
Abundance of whiteflies (KB) & 0,9872 & 0,0127 & 77,8593 & 0,000 \\
Alternative host plant (TIAK) & 1,0936 & 0,2740 & 3,9907 & 0,000 \\
\hline
\end{tabular}

Abundant whiteflies showed a positive effect on the yellowing disease incidence. This is consistent with the statement of [18] that whiteflies as vectors of virus in the spread of yellowing disease by persistence from infected plants (alternative host) to healthy yard long bean crops. The existence of alternative hosts also has a positive effect on the incidence of yellowing disease as a reservoir for the virus, where the virus is able to adapt well to the different types of plants such as weeds and crops [3]. This is consistent with those reported by [27] that the presence of weeds that show symptoms or not (latent infection) caused by yellowing viral infections needs to be watched out because it can serve as a source of inoculum and alternative host viruses. It is very important because it can be used by viruses to multiply and form new strains so that the spread of the virus is on the rise.

The occurrence of yellowing disease as epidemiological viral diseases in yard long beans because of the existence of alternative host plants as a source of inoculum and insect vector whiteflies that has a high mobility in the spread of the virus. During 1980, Begomovirus disease and the vector whitefly, Bemisia tabaci emerged as serious problems in many vegetable and pulse crops [14]. The interaction between the host plant and the virus, host and vector, as well as viruses and vectors have become one entity. If the plant's virus inoculum source is not available it can be ascertained the incidence of yellowing disease will not occur despite the vector around long bean crop land.

\section{Conclusion}

Increased incidence of yellowing disease in the yard long bean cultivation centers in Bali positively and significantly correlated with the increase of population abundance of insect vectors whiteflies, B. tabaci and the existence of alternative host plants such as weeds and other crop symptomatic yellowing with patterns of relationships KPK $=1,2265 \mathrm{~KB}^{0,9872} \mathrm{TIAK}^{1,0936}$.

\section{References}

[1] Agustí-Brisach, C., Gramaje, D., León, M., García-Jiménez, J., \& Armengol, J. (2011). Evaluation of vineyard weeds as potential hosts of black-foot and petri disease pathogens. Plant Disease, 95(7), 803810. https://doi.org/10.1094/pdis-12-10-0888

[2] Apablaza, G., Apablaza, J., Reyes, P., \& Moya, E. (2003). Determination of viral diseases and insect vectors on weeds adjacent to fields of vegetable crops. Ciencia e Investigación Agraria, 30(3), 175-186. https://doi.org/10.7764/rcia.v30i3.1312

[3] Barreto, S. S., Hallwass, M., Aquino, O. M., \& Inoue-Nagata, A. K. (2013). A study of weeds as potential inoculum sources for a tomato-infecting begomovirus in central Brazil. Phytopathology®, 103(5), 436444. https://doi.org/10.1094/phyto-07-12-0174-r

[4] Bueno, V. H. P. (2016). New South American mirid predators attack important lepidopteran pests and 
whiteflies, but also the host plant. 2016 International Congress of Entomology. http://dx.doi.org/10.1603/ice.2016.92206

[5] Cania, D., Nova, B., Runifah, T., Hidayati, R., Anwar, A., \& Jamsari, J. (2021). Molecular diversity of Pepper Yellow Leaf Curl Virus (PepYLCV) Infecting Capsicum annuum in West Sumatra. IOP Conference Series: Earth and Environmental Science, 741(1), 012038. https://doi.org/10.1088/17551315/741/1/012038

[6] Chavan, V. M. (2015). Plant virus disease spread through insect vectors and their management. In New Horizons in Insect Science: Towards Sustainable Pest Management (pp. 147-158). Springer India. http://dx.doi.org/10.1007/978-81-322-2089-3_15

[7] Czosnek, H., \& Ghanim, M. (2011). Bemisia tabaci - Tomato Yellow Leaf Curl Virus Interaction Causing Worldwide Epidemics. In The Whitefly, Bemisia tabaci (Homoptera: Aleyrodidae) Interaction with Geminivirus-Infected Host Plants (pp. 51-67). Springer Netherlands. http://dx.doi.org/10.1007/978-94007-1524-0_3

[8] Damayanti, T. A., Alabi, O. J., Rauf, A., \& Naidu, R. A. (2010). The Occurrence of Bean common mosaic virus and Cucumber mosaic virus in Yardlong Beans in Indonesia. Plant Disease, 94(4), 478-478. https://doi.org/10.1094/pdis-94-4-0478b

[9] Ghosh, S., \& Ghanim, M. (2021). Factors Determining Transmission of Persistent Viruses by Bemisia tabaci and Emergence of New Virus-Vector Relationships. Viruses, 13(9), 1808. https://doi.org/10.3390/v13091808

[10] Hidayat, S. H., Chatchawankanpanich, O., \& Aidawati, N. (2008). Molecular identification and sequence analysis of tobacco leaf curl begomovirus from jember, East Java, Indonesia. HAYATI Journal of Biosciences, 15(1), 13-17. https://doi.org/10.4308/hjb.15.1.13

[11] Ilyas, M., Qazi, J., Mansoor, S., \& Briddon, R. W. (2010). Genetic diversity and phylogeography of begomoviruses infecting legumes in Pakistan. Journal of General Virology, 91(8), 2091-2101. https://doi.org/10.1099/vir.0.020404-0

[12] Kim, K. S. (1984). Ultrastructure ofDatura stramoniumInfected with an Euphorbia Virus Suggestive of a Whitefly-Transmitted Geminivirus. Phytopathology, 74(2), 236. https://doi.org/10.1094/phyto-74-236

[13] Mahy, B. W. J., and Regenmortel, M. H. V. V. 2010. Desk Encyclopedia of Plant and Fungal Virology. San Diego: Academic Press.

[14] Malathi, V. G., Renukadevi, P., Chakraborty, S., Biswas, K. K., Roy, A., Sivalingam, P. N., Venkataravanappa, V., \& Mandal, B. (2017). Begomoviruses and their satellites occurring in India: Distribution, diversity and pathogenesis. In A Century of Plant Virology in India (pp. 75-177). Springer Singapore. http://dx.doi.org/10.1007/978-981-10-5672-7_5

[15] Marutani, M. (2009). Field performance and nodulation of yardlong bean in the humid tropics. International Journal of Vegetable Science, $15(2), \quad 133-141$. https://doi.org/10.1080/19315260802570010

[16] Morales, F. J., \& Anderson, P. K. (2001). The emergence and dissemination of whitefly-transmitted geminiviruses in Latin America. Archives of Virology, 146(3), 415-441. https://doi.org/10.1007/s007050170153

[17] Mulyadi, D., Sulandari, S., Hartono, S., \& Somowiyarjo, S. (2021). Distribution, host range and detection of seed-borne yellow mosaic disease on yardlong beans (Vigna unguiculata subsp. sesquipedalis L.) in the special region of Yogyakarta, Indonesia. Biodiversitas Journal of Biological Diversity, 22(9). https://doi.org/10.13057/biodiv/d220942

[18] Navas-Castillo, J., Sánchez-Campos, S., Díaz, J. A., Sáez-Alonso, E., \& Moriones, E. (1999). Tomato yellow leaf curl virus-is causes a novel disease of common bean and severe epidemics in tomato in Spain. Plant Disease, 83(1), 29-32. https://doi.org/10.1094/pdis.1999.83.1.29

[19] Nawaz-ul-Rehman, M. S., \& Fauquet, C. M. (2009). Evolution of geminiviruses and their satellites. FEBS Letters, 583(12), 1825-1832. https://doi.org/10.1016/j.febslet.2009.05.045

[20] Noda, H. (2016). Mungbean yellow mosaic India virus strains and weed begomoviruses transmitted byBemisia tabaciin central India. 2016 International Congress of Entomology. http://dx.doi.org/10.1603/ice.2016.114002

[21] Nurulita, S., Hendrastuti, S., Mutaqin, K. H., \& Thomas, J. E. (2015). Molecular Characterization of Begomovirus Infecting Yard Long Bean (Vigna unguiculata subsp. sesquipedalis L.) in Java, Indonesia. Biotropia, 22(1). https://doi.org/10.11598/btb.2015.22.1.401

[22] Pakkianathan, B. C., Kontsedalov, S., Lebedev, G., Mahadav, A., Zeidan, M., Czosnek, H., \& Ghanim, M. (2015). Replication of Tomato Yellow Leaf Curl Virus in Its Whitefly Vector, Bemisia tabaci. Journal of Virology, 89(19), 9791-9803. https://doi.org/10.1128/jvi.00779-15

[23] Pramanik, D., Shelake, R. M., Park, J., Kim, M. J., Hwang, I., Park, Y., \& Kim, J.-Y. (2021). CRISPR/Cas9-Mediated generation of pathogen-resistant tomato against tomato yellow leaf curl virus and powdery mildew. International Journal of Molecular Sciences, 22(4), 1878. 
https://doi.org/10.3390/ijms22041878

[24] Purwaningsih, N. N. A., Puspawati, N. M., \& Nyana, I. D. N. (2016). Pengaruh penyakit virus mosaik dan kuning terhadap hasil panen tanaman kacang panjang (Vigna sinensis L.) di Desa Perean, Baturiti, Tabanan. E-Jurnal Agroekoteknologi Tropika, 5(3), 212-221.

[25] Rey, M. E. C., Ndunguru, J., Berrie, L. C., Paximadis, M., Berry, S., Cossa, N., Nuaila, V. N., Mabasa, K. G., Abraham, N., Rybicki, E. P., Martin, D., Pietersen, G., \& Esterhuizen, L. L. (2012). Diversity of dicotyledenous-infecting geminiviruses and their associated DNA molecules in Southern Africa, including the South-West Indian Ocean Islands. Viruses, 4(9), 1753-1791. https://doi.org/10.3390/v4091753

[26] Rosell, R. C., Torres-Jerez, I., \& Brown, J. K. (1999). Tracing the geminivirus-whitefly transmission pathway by polymerase chain reaction in whitefly extracts, saliva, hemolymph, and honeydew. Phytopathology®, 89(3), 239-246. https://doi.org/10.1094/phyto.1999.89.3.239

[27] Roye, M. E., McLaughlin, W. A., Nakhla, M. K., \& Maxwell, D. P. (1997). Genetic Diversity Among Geminiviruses Associated with the Weed Species Sida spp., Macroptilium lathyroides, and Wissadula amplissima from Jamaica. Plant Disease, 81(11), 1251-1258. https://doi.org/10.1094/pdis.1997.81.11.1251

[28] Saputra, I. G. P. E. 2015 Detectionof Mungbean Yellow Mosaic Virus (MYMV) on Yard Long Bean (Vigna sinensis L.) and Weeds using Polymerase Chain Reaction (PCR) Method. [Essay]. Denpasar: (ID): Scholar School Udayana University.

[29] Selangga, D. G. W., \& Listihani, L. (2021). MOLECULAR IDENTIFICATION OF Pepper yellow leaf curl Indonesia virus ON CHILI PEPPER IN NUSA PENIDA ISLAND. JURNAL HAMA DAN PENYAKIT TUMBUHAN TROPIKA, 21(2), 97-102. https://doi.org/10.23960/jhptt.22197-102

[30] Shahid, M. S., Ikegami, M., \& Natsuaki, K. T. (2012). First report of Mungbean yellow mosaic India virus on Lima bean affected by yellow mosaic disease in Nepal. Australasian Plant Disease Notes, 7(1), 85-89. https://doi.org/10.1007/s13314-012-0055-9

[31] Suma, A., Latha, M., John, J. K., Aswathi, P. V., Pandey, C. D., \& Ajinkya, A. (2021). Yard-long bean. In The Beans and the Peas (pp. 153-172). Elsevier. http://dx.doi.org/10.1016/b978-0-12-8214503.00010-x

[32] Yang, X., Wang, B., Luan, J., Xie, Y., Liu, S., \& Zhou, X. (2017). Molecular variation of tomato yellow leaf curl virus in the insect vector Bemisia tabaci. Scientific Reports, 7(1). https://doi.org/10.1038/s41598017-16330-4 